\title{
ANALISIS EFISIENSI EKONOMI PENGGUNAAN FAKTOR PRODUKSI PADA BEBERAPA JENIS USAHATANI SAYURAN DI KECAMATAN SUNGAI GELAM KABUPATEN MUARO JAMBI
}

\author{
Anita Sisilia Silitonga ${ }^{1)}$,Yusma Damayanti ${ }^{2)}$ dan Saidin Nainggolan ${ }^{2)}$ \\ 1) Alumni Jurusan Agribisnis Fakultas Pertanian Universitas Jambi, \\ 2) Staf Pengajar Jurusan Agribisnis Fakultas Pertanian Universitas Jambi \\ Email: anitasisilias@ymail.com
}

\begin{abstract}
ABSTRAK
Penelitian ini bertujuan: (1) menganalisis pengaruh faktor produksi terhadap jumlah produksi usahatani sayuran (sawi, bayam dan kangkung) di Kecamatan Sungai Gelam Kabupaten Muaro Jambi, dan (2) menganalisis efisiensi ekonomi penggunaan faktor produksi beberapa jenis usahatani sayuran (sawi, bayam dan kangkung) di Kecamatan Sungai Gelam Kabupaten Muaro Jambi. Penelitian ini dilaksanakan pada tanggal 31 Agustus hingga 31 September 2015 di dua desa yaitu Desa Kebon IX dan Desa Mekar Jaya pada beberapa jenis usahatani sayuran yaitu sawi, bayam dan kangkung di Kecamatan Sungai Gelam Kabupaten Muaro Jambi. Masing-masing usahatani sayuran terdiri dari 30 orang petani. Metode yang digunakan adalah analisis regresi linier berganda dengan menggunakan model fungsi produksi Cobb-Douglas dan analisis efisiensi ekonomi.

Hasil analisis regresi menunjukkan bahwa penggunaan faktor produksi secara bersama-sama berpengaruh nyata terhadap produksi sawi, bayam dan kangkung. Secara parsial faktor produksi luas lahan, benih dan pupuk kandang masing-masing berpengaruh nyata terhadap produksi sawi dan kangkung, sedangkan luas lahan, benih dan pupuk urea berpengaruh nyata terhadap produksi bayam. Hasil analisis efisiensi ekonomi penggunaan faktor produksi yang belum efisien pada usahatani sawi yaitu luas lahan, benih dan pupuk kandang, pada usahatani bayam meliputi luas lahan, benih dan pupuk urea, sedangkan pada usahatani kangkung meliputi benih dan pupuk kandang. Oleh karena itu penggunaan faktor produksinya perlu ditambah, agar mencapai efisien.
\end{abstract}

Kata kunci: Efisiensi Ekonomi, Faktor Produksi, Usahatani Sayuran.

\begin{abstract}
This study aims to: (1) analyze the influence of factors of production to the amount of farm production of vegetables (collards, spinach and kale) in Sungai Gelam Muaro Jambi, and (2) to analyze the economic efficiency of use of production factors some kind of vegetables farming (collards, spinach and kale) in Sungai Gelam Muaro Jambi. The research was conducted on 31 August to 31 September 2015 in two villages of Kebon IX and Mekar Jaya Village on some types of vegetables farming are collards, spinach and kale in Sungai Gelam Muaro Jambi. Each vegetable farm consists of 30 farmers. The method used is multiple linear regression analysis using a model of the Cobb-Douglas production function and the analysis of economic efficiency.

Regression analysis showed that the use of production factors together significantly affected the production of collards, spinach and kale. Partially factors of production land, seeds and manure each significant effect on the production of collards and kale, while the area of land, seed and fertilizer urea significant effect on the production of spinach. Results of the analysis of economic efficiency of use of factors of production are not efficient at farming collards namely land, seed and manure, the spinach farm covers an area of land, seed and fertilizer urea, while the spinach farm includes seed and manure. Therefore the use of factors of production should be increased, in order to achieve efficient.
\end{abstract}

Keywords: Economic Efficiency, Production Factor, Vegetables Farm 


\section{PENDAHULUAN}

Komoditas tanaman hortikultura merupakan salah satu komoditas pertanian yang strategis dan merupakan salah satu sub sektor penting dalam pembangunan pertanian. Pembangunan pertanian diarahkan untuk meningkatkan pendapatan dan taraf hidup petani, memperluas kesempatan kerja serta mengisi dan memperluas pasar. Salah satu komoditas hortikultura yang dapat memberikan pendapatan bagi petani adalah sayuran. Sayuran mempunyai nilai ekonomis yang tinggi karena umur tanaman sayuran yang relatif pendek sehingga dapat dengan cepat menghasilkan dan dapat terserap cepat di pasar karena merupakan salah satu komponen susunan menu keluarga yang tidak dapat ditinggalkan.

Namun, tanaman hortikultura khususnya sayuran mempunyai karakteristik tertentu yaitu produk mudah rusak, komponen utama mutu produk ditentukan oleh air dan bukan oleh kandungan bahan kering karena konsumsinya dalam keadaan segar, ketersediaan produk bersifat musiman, dan harga produk ditentukan oleh kualitas bukan kuantitas. Adapun ciri-ciri produk diatas menjelaskan bahwa pembudidayaan tanaman hortikultura harus dilakukan secara intensif, mulai dari pemanenan, pengangkutan, sampai pada pemasaran. Oleh karena itu, budidaya tanaman hortikultura bersifat padat modal dan padat karya. Secara ringkas dapat dikatakan bahwa tanaman hortikultura adalah tanaman yang pembudidayaannya menghendaki masukan (input) yang tinggi, namun menghasilkan keluaran (output) yang juga tinggi per satuan luas per satuan waktu (Zulkarnain, 2010). Sayuran merupakan jenis produk pertanian yang dikonsumsi setiap saat, sehingga sayuran mempunyai nilai jual cukup tinggi. Adapun beberapa jenis sayuran yang berpotensi untuk diusahakan sekaligus memberi keuntungan yang cukup tinggi antara lain sawi, bayam, kangkung, mentimun, kacang panjang dan sayuran semusim lainnya. Sayuran daun seperti sawi, bayam dan kangkung adalah beberapa jenis sayuran yang paling banyak diusahakan karena dilihat dari aspek budidayanya sangat mudah dibanding dengan jenis tanaman sayuran lainnya. Selain itu, masa tanamnya yang relatif pendek yaitu antara 1-1,5 bulan per musim tanam dapat dengan cepat mendapatkan hasil.

Provinsi Jambi tahun 2013 dengan luas panen $20.157 \mathrm{Ha}$, mampu menghasilkan produksi sayuran sebesar 237.225 ton. Pencapaian produksi pada tahun 2013 ini masih tergolong rendah dibandingkan dengan produksi sayuran pada tahun 2010 yang mencapai 1.786 .842 ton dengan luas panen $19.570 \mathrm{Ha}$. Kenaikan atau penurunan produksi terjadi sebagian besar disebabkan oleh faktor cuaca dan iklim yang tidak menentu serta perubahan penggunaan faktor-faktor produksi. Pada dasarnya petani akan mengubah penggunaan faktor-faktor produksi apabila dapat meningkatkan pendapatannya. Kabupaten Muaro Jambi merupakan salah satu daerah penghasil sayuran di Provinsi Jambi. Kabupaten Muaro Jambi dengan luas panen seluas 1300 Ha mampu memproduksi sayuran sejumlah 5052 ton dengan tingkat produktivitas 3,88 ton/Ha. Luas panen dan produktivitas tanaman sayuran di Kabupaten Muaro Jambi relatif kecil dibandingkan dengan kabupaten lain di Provinsi Jambi. Kabupaten Muaro Jambi termasuk dalam kategori wilayah dataran rendah dimana pada wilayah ini memiliki ketinggian dari 0-100 meter di atas permukaan laut. Namun, kelebihan dari beberapa jenis sayuran seperti sawi, bayam dan kangkung adalah dapat tumbuh baik di berbagai ketinggian, baik dataran rendah maupun dataran tinggi. Beberapa jenis sayuran daun seperti sawi, bayam, kangkung di Kabupaten Muaro Jambi terdapat di beberapa kecamatan, salah satu diantara kecamatan yang paling banyak mengusahakan beberapa jenis sayuran tersebut adalah Kecamatan Sungai Gelam. Kecamatan Sungai Gelam merupakan luas areal tanam sayuran daun terbesar di Kabupaten Muaro Jambi. Kecamatan ini juga merupakan salah satu pemasok sayur-sayuran bagi masyarakat di Kota Jambi karena antara pasar dengan tempat produksi sayuran cukup terjangkau selain itu juga karena beberapa jenis sayuran tersebut memliki nilai komersial yang relatif baik. Kecamatan Sungai Gelam terdiri dari 15 Desa, dimana dua diantaranya merupakan desa terbesar dalam memproduksi beberapa jenis sayuran yaitu Desa Kebon IX dan Desa Mekar Jaya. Pemilihan lokasi penelitian di dua desa tersebut selain terbesar dalam memproduksi sayuran, juga karena menurut penyuluh pertanian lapangan di daerah penelitian (PPL) desa tersebut merupakan wilayah yang di arahkan dalam pengembangan usahatani sayuran di Kecamatan Sungai Gelam. 
Pada tahun 2012 hingga 2013 produktivitas beberapa jenis sayuran terlihat stabil seperti sawi yaitu 3,2 ton/Ha, bayam dan kangkung sebesar 1,6 ton/Ha, namun jika dibandingkan dengan skala produktivitas sayuran daun seperti sawi, bayam dan kangkung di wilayah dataran rendah seharusnya mampu mencapai 5-10 ton/Ha tiap tahunnya (Nazaruddin, 1999). Hal ini menunjukkan bahwa produktivitas beberapa jenis sayuran tersebut di Kecamatan Sungai Gelam masih sangat jauh tertinggal. Rendahnya tingkat produktivitas usahatani disebabkan oleh faktor dari dalam lingkungan usahatani. Salah satu faktor dari dalam lingkungan usahatani adalah faktor-faktor produksi. Penggunaan faktor-faktor produksi dinilai sangat penting karena mempunyai pengaruh terhadap produksi yang dihasilkan. Menurut Nurung 2002 dalam Wibisono (2011) penggunaan faktor produksi dalam usahatani dilaksanakan secara turun-menurun, sehingga penggunaan faktor produksi tidak ditakar secara persis. Hal ini yang menyebabkan penggunaan faktor produksi tidak efisien. Efisiensi produksi secara ekonomis memerlukan prasyarat informasi harga jual produksi dan harga beli faktorfaktor produksi yang digunakan dalam usahatani. Hal ini yang menyebabkan penilaian efisiensi produksi secara ekonomis disebut sebagai efisiensi harga. Untuk memperoleh nilai produksi yang ekonomis maka petani harus menggunakan faktor produksi dengan ketentuan Nilai Produk Marginal (NPM) dengan harga masing-masing faktor produksi sama besarnya. Nilai Produksi Marginal (NPM) dari setiap unit tambahan output sama dengan harga dari setiap unit input (Pxi).

Berdasarkan latar belakang diatas, maka tujuan dalam penelitian ini adalah (1) untuk mengetahui faktor-faktor apa saja yang mempengaruhi produksi usahatani sayuran (sawi, bayam dan kangkung) di Kecamatan Sungai Gelam Kabupaten Muaro Jambi dan (2) untuk menganalisis efisiensi ekonomi penggunaan faktor produksi beberapa jenis usahatani sayuran (sawi, bayam dan kangkung) di Kecamatan Sungai Gelam Kabupaten Muaro Jambi.

\section{METODE PENELITIAN}

Penelitian ini dilaksanakan di Desa Kebon IX dan Desa Mekar Jaya di Kecamatan Sungai Gelam dengan penarikan sampel yang dilakukan secara sengaja (purposive) dengan pertimbangan bahwa kedua desa tersebut merupakan desa dengan daerah terluas dalam mengusahakan sayuran daun di Kecamatan Sungai Gelam. Penentuan sampel responden di Desa Kebon IX dan Desa Mekar Jaya dilakukan dengan teknik Snowball Sampling (pengambilan sampel bola salju). Dengan teknik ini, mulamula peneliti mencari responden yang sesuai dengan kriteria yang ditetapkan, kemudian dari responden ini akan menunjuk atau mengajak temannya yang lain untuk dijadikan sampel, dan seterusnya sehingga jumlah sampel semakin banyak (Rianse, Usman dan Abdi, 2012).

Jika terdapat satu orang petani mengusahakan minimal salah satu jenis sayuran dari beberapa jenis sayuran yang ditentukan (sawi, bayam dan kangkung) maka petani tersebut sudah bisa dikatakan sebagai responden. Apabila terdapat lebih dari 30 petani yang masing-masing petani mengusahakan ketiga jenis sayuran tersebut diatas, maka responden yang diambil adalah 30 orang petani yang mengusahakan ketiga jenis sayuran tersebut. Hal ini menandakan bahwa penentuan responden disesuaikan dengan kondisi lapangan. Objek dalam penelitian ini adalah petani yang melakukan usahatani sayuran untuk beberapa jenis sayuran seperti sawi, bayam dan kangkung. Adapun pelaksanaan penelitian ini dilaksanakan pada tanggal 31 Agustus 2015 sampai tanggal 31 September 2015.

Untuk mengkaji hubungan fungsional antara faktor-faktor produksi dengan produksi pada usahatani sayuran sawi, bayam dan kangkung digunakan analisis regresi dengan model fungsi produksi Cobb-Douglas. Persamaan fungsi tersebut dapat ditulis sebagai berikut :

$Y_{i}=a X_{1} b_{1} \cdot X_{2} b_{2} . X_{3} b_{3} \cdot X_{4} b_{4} \cdot X_{5} b_{5} . X_{6} b_{6} . e \mu$

Keterangan :

$\mathrm{Y}_{\mathrm{i}} \quad=$ Produksi sayuran ke-i $(\mathrm{Kg} / \mathrm{MT})$

a $\quad=$ Konstanta

$\mathrm{X}_{1}=$ Luas lahan $(\mathrm{Ha})$

$\mathrm{X}_{2}=$ Benih $(\mathrm{Kg})$ 
$\mathrm{X}_{3} \quad=$ Pupuk kandag $(\mathrm{Kg})$

$\mathrm{X}_{4} \quad=$ Pupuk urea $(\mathrm{Kg})$

$X_{5} \quad=$ Pestisida (Liter)

$\mathrm{X}_{6} \quad=$ Tenaga kerja (HOK)

$\mathrm{b}_{1}-\mathrm{b}_{6}=$ Koefisien regresi variabel $\mathrm{X}_{1}-\mathrm{X}_{6}$

$\mathrm{i} \quad=$ Sawi (Kg/MT), Bayam ( Kg/MT) dan Kangkung ( Kg/MT)

$\mathrm{u} \quad=$ Kesalahan (disturbance term)

Untuk memudahkan pendugaan terhadap persamaan di atas, maka persamaan tersebut ditransformasikan ke dalam bentuk Logaritma :

$\log Y_{i}=\log a+b_{1} \log X_{1}+b_{2} \log X_{2}+b_{3} \log X_{3}+b_{4} \log X_{4}+b_{5} \log X_{5}+b_{6} \log X_{6}+\mu$

Untuk menguji apakah variabel - variabel bebas secara bersama-sama berpengaruh terhadap variabel terikat digunakan uji $\mathrm{F}$ dengan menghitung terlebih dahulu besarnya variabel tidak bebas yang dapat diterangkan oleh variabel bebas yang dapat dihitung dengan menggunakan koefisien determinasi $\left(R^{2}\right)$ (Gujarati, 2003)

$$
\mathrm{R}^{2}=\frac{\mathrm{b}_{\mathrm{i}} \sum \mathrm{x}_{\mathrm{i}} \mathrm{y}_{\mathrm{i}}}{\sum \mathrm{y}_{\mathrm{i}}{ }^{2}}
$$

Untuk mengetahui pengaruh masing-masing masukan terhadap hasil produksi sayuran sawi, bayam dan kangkung digunakan uji keberartian koefisien regresi dengan uji t, dengan rumus sebagai berikut :

$$
t_{\text {hit }}=b_{i} / S b_{i}
$$

Dimana :

$\mathrm{T}_{\text {hit }} \quad=$ nilai t hitung

$b_{i} \quad=$ koefisien regresi perkiraan ke- $b_{i}$

$\mathrm{Sb}_{\mathrm{i}} \quad=$ standard error perkiraan ke- $b_{\mathrm{i}}$

i $\quad=1,2,3, \ldots .6$

Dengan hipotesis :

$$
\mathrm{Hi}=\mathrm{bi}=0
$$

Pada tingkat signifikasi $\alpha$ sebesar $5 \%$ maka:

a. Jika $\mathrm{t}$ hitung $\leq \mathrm{t}$ tabel : Hi ditolak berarti input ke-i tidak berpengaruh nyata terhadap hasil produksi sayuran sawi, bayam dan kangkung.

b. Jika $\mathrm{t}$ hitung $>\mathrm{t}$ tabel : Hi diterima berarti masukan ke-i berpengaruh nyata terhadap hasil produksi sayuran sawi, bayam dan kangkung.

Untuk mengkaji penggunaan faktor produksi yang berupa luas lahan, benih, pupuk kandang, pupuk urea, pestisida dan tenaga kerja pada usahatani sawi, bayam dan kangkung mencapai tingkat efisiensi ekonomi tertinggi, persamaan demikian tidaklah cukup, sehingga masing-masing harus dikalikan dengan harga hasil produksinya, persamaannya menjadi:

$$
P_{y} \frac{N P M_{x 1}}{P_{x 1}}=P_{y} \frac{N P M_{x 2}}{P_{x 2}}=P_{y} \frac{N P M_{x 3}}{P_{x 3}}=P_{y} \frac{N P M_{x 4}}{P_{x 4}}=P_{y} \frac{N P M_{x 5}}{P_{x 5}}=P_{y} \frac{N P M_{x 6}}{P_{x 6}}=1
$$

Dimana :

$$
\begin{array}{ll}
\mathrm{NPMx}_{\mathrm{i}} & =\text { Nilai produk marginal untuk masukan } \mathrm{X}_{\mathrm{i}} \\
\mathrm{Px}_{\mathrm{i}} & =\text { Harga masukan } \mathrm{X}_{\mathrm{i}} \\
\mathrm{Py} & =\text { Harga hasil produksi }
\end{array}
$$

Kriteria yang digunakan sebagai berikut :
a. Apabila nilai : $\left(\mathrm{NPMx}_{\mathrm{i}}\right) /\left(\mathrm{Px}_{\mathrm{i}}\right)=1$ : artinya pengunaaan input $\mathrm{x}_{\mathrm{i}}$ mencapai nilai efisiensi ekonomi
b. Apabila nilai : $\left(\mathrm{NPMx}_{\mathrm{i}}\right) /\left(\mathrm{Px}_{\mathrm{i}}\right)>1$ : artinya pengunaaan input $\mathrm{x}_{i}$ belum mencapai nilai efisiensi ekonomi
c. Apabila nilai : $\left(\mathrm{NPMx}_{\mathrm{i}}\right) /\left(\mathrm{Px}_{\mathrm{i}}\right)<1$ : artinya pengunaaan input $\mathrm{x}_{\mathrm{i}}$ tidak efisien 


\section{Identitas Petani \\ Umur}

Umur dapat mempengaruhi fisik dan cara berpikir petani. Secara umum dapat dikatakan bahwa petani yang masih berusia muda dan sehat fisik maupun mentalnya akan memiliki kemampuan fisik dan produktivitas kerja yang lebih tinggi. Menurut Hernanto (1991), pada umumnya petani yang berumur makin tua, pertimbangan dan pengambilan keputusannya relatif lama dibandingkan petani yang berumur lebih muda dan sehat, memiliki kemampuan fisik yang lebih cepat menerima hal-hal baru yang dianjurkan, karena petani yang berusia muda lebih berani mengambil resiko. Dari hasil penelitian terhadap 41 orang petani sayuran di daerah penelitian, umur petani responden berkisar antara 33 tahun sampai dengan 75 tahun. Untuk lebih jelasnya, dapat dilihat pada tabel berikut ini :

Tabel 1. Distribusi Frekuensi Dan Persentase Petani Responden Berdasarkan Umur Di Daerah Penelitian Tahun 2015

\begin{tabular}{ccc}
\hline $\begin{array}{c}\text { Umur } \\
\text { (Tahun) }\end{array}$ & $\begin{array}{c}\text { Frekuensi } \\
\text { (Orang) }\end{array}$ & $\begin{array}{c}\text { Persentase } \\
(\%)\end{array}$ \\
\hline $33-39$ & 10 & 24,39 \\
$40-46$ & 9 & 21,95 \\
$47-53$ & 12 & 29,26 \\
$54-60$ & 5 & 12,19 \\
$61-67$ & 2 & 4,87 \\
$68-74$ & 2 & 4,87 \\
$75-81$ & 1 & 2,43 \\
\hline Jumlah & 41 & 100 \\
\hline
\end{tabular}

Tabel 1 menjelaskan bahwa umur petani responden yang paling banyak atau dominan berada pada interval 47 - 53 tahun yaitu sebanyak 12 orang dengan persentase sebesar $29,26 \%$ dari total petani responden. Dari data tersebut dapat diketahui bahwa mayoritas petani responden yang berusahatani sayuran di Kecamatan Sungai Gelam merupakan petani yang berada pada usia produktif. Pernyataan tersebut didukung oleh pernyataan Hernanto (1991), usia produktif berada pada usia 1550 tahun. Dengan kondisi petani responden yang rata-rata berumur produktif maka diharapkan mampu mengelola usahataninya secara maksimal guna meningkatkan produksi.

\section{Pengalaman Berusahatani}

Menurut Suratiyah (2011), kecakapan seseorang menentukan kinerja seseorang. Seseorang yang lebih cakap tentu saja prestasinya lebih tinggi dibandingkan dengan yang kurang cakap. Kecakapan ditentukan oleh pendidikan, pengetahuan dan pengalaman. Jadi, semakin lama pengalaman dalam berusahatani maka semakin cakap petani tersebut karena petani dapat belajar dari pengalaman yang telah lalu untuk menuju yang lebih baik, karena pengalaman merupakan pendidikan non-formal yang sangat bermanfaat. Tingkat pengalaman berusahatani petani di daerah penelitian dapat dilihat pada tabel berikut :

Tabel 2. Distribusi Frekuensi Dan Persentase Petani Responden Berdasarkan Pengalaman Berusahatani Di Daerah Penelitian Tahun 2015

\begin{tabular}{ccc}
\hline $\begin{array}{c}\text { Pengalaman Berusahatani } \\
\text { (Tahun) }\end{array}$ & $\begin{array}{c}\text { Jumlah } \\
\text { (orang) }\end{array}$ & $\begin{array}{c}\text { Persentase } \\
(\%)\end{array}$ \\
\hline $4-8$ & 5 & 12,19 \\
$9-13$ & 3 & 7,31 \\
$14-18$ & 14 & 34,14 \\
$19-23$ & 13 & 31,70 \\
$24-28$ & 3 & 7,31 \\
$29-33$ & 3 & 7,31 \\
\hline Jumlah & 41 & 100 \\
\hline
\end{tabular}


Berdasarkan Tabel 2, menunjukkan bahwa sebagian besar petani responden berpengalaman usahatani berada pada interval 14-18 tahun yaitu terdapat 14 orang petani dengan persentase 34,14 $\%$ dari total petani. Keadaan petani responden di daerah penelitian ini dapat dikatakan sudah berpengalaman dalam berusahatani sehingga kemungkinan besar lebih mampu mengelola usahatani dengan baik dan mampu menghasilkan produk yang berkualitas, serta mampu meningkatkan kuantitas produksi sayuran.

\section{Jumlah Anggota Keluarga}

Jumlah anggota keluarga sangat berperan dalam pengelolaan usahatani, karena semakin banyak jumlah anggota keluarga maka semakin tinggi kebutuhan yang harus di penuhi oleh petani dan semakin tinggi tanggung jawab petani untuk memenuhi kebutuhan. Menurut Hernanto (1991), menyatakan bahwa jumlah anggota keluarga sangat berpengaruh dalam pengelolaan suatu kegiatan ekonomi, khususnya terhadap kegiatan ekonomi pada usahatani petani tersebut. Untuk mengetahui jumlah anggota keluarga petani sayuran di daerah penelitian dapat dilihat pada tabel berikut :

Tabel 3. Distribusi Frekuensi Dan Persentase Petani Responden Berdasarkan Jumlah Anggota Keluarga Petani Di Daerah Penelitian Tahun 2015

\begin{tabular}{ccc}
\hline $\begin{array}{c}\text { Jumlah Anggota } \\
\text { Keluarga (orang) }\end{array}$ & $\begin{array}{c}\text { Jumlah } \\
\text { (orang) }\end{array}$ & $\begin{array}{c}\text { Persentase } \\
(\%)\end{array}$ \\
\hline $2-3$ & 19 & 46,34 \\
$4-5$ & 20 & 48,78 \\
$6-7$ & 2 & 4,87 \\
\hline Jumlah & 41 & 100 \\
\hline
\end{tabular}

Berdasarkan Tabel 3, dapat diketahui bahwa jumlah anggota keluarga petani responden yang paling dominan berada pada interval $4-5$ orang, yaitu sebanyak 20 orang dengan persentase 48,78 $\%$ dari total petani. Jumlah anggota keluarga sangat berkaitan dengan penggunaan tenaga kerja dari dalam keluarga. Apabila anggota keluarga berada dalam usia produktif atau tidak sekolah maka dapat membantu dalam pengelolaan usahatani sayuran sehingga tidak perlu mengeluarkan banyak biaya tenaga kerja dari luar keluarga. Jika pengeluaran biaya tenaga kerja kecil maka pendapatan yang diperoleh petani dari usahatani juga akan lebih besar.

\section{Penggunaan Faktor Produksi Usahatani Sayuran}

Alokasi penggunaan faktor - faktor produksi merupakan kunci utama dalam mencapai produksi yang tinggi dari suatu usahatani. Secara umum input yang digunakan diantaranya adalah lahan, benih, pupuk, obat-obatan dan tenaga kerja. Penggunaan faktor-faktor produksi pada beberapa jenis usahatani sayuran dapat dilihat pada Tabel 4:

Tabel 4. Rata-rata Penggunaan Faktor Produksi Pada Beberapa Jenis Usahatani Sayuran di Daerah Penelitian Tahun 2015

\begin{tabular}{clccc}
\hline \multirow{2}{*}{ No } & \multicolumn{1}{c}{ Faktor Produksi } & \multicolumn{3}{c}{ Rata-rata } \\
\cline { 3 - 5 } & & Sawi & Bayam & Kangkung \\
\hline 1 & Luas Lahan $\left(\mathrm{X}_{1}\right)(\mathrm{Ha})$ & 0,07 & 0,058 & 0,04 \\
2 & Benih $\left(\mathrm{X}_{2}\right)(\mathrm{Kg})$ & 0,31 & 1,55 & 3,46 \\
3 & Pupuk Kandang $\left(\mathrm{X}_{3}\right)(\mathrm{Kg})$ & 310,3 & 292,66 & 271 \\
4 & Pupuk Urea $\left(\mathrm{X}_{4}\right)(\mathrm{Kg})$ & 4,16 & 3,33 & 3,35 \\
5 & Pestisida $\left(\mathrm{X}_{5}\right)(\mathrm{Ltr})$ & 0,13 & 0,07 & 0,058 \\
6 & Tenaga Kerja $\left(\mathrm{X}_{6}\right)(\mathrm{HOK})$ & 13 & 7,41 & 9,48 \\
\hline
\end{tabular}

Dari Tabel 4 diatas terlihat bahwa petani sampel di daerah penelitian ini memiliki dan menggunakan faktor produksi tersebut pada kegiatan usahatani sayuran. Penggunaan secara efisien faktor produksi pada beberapa jenis usahatani sayuran di daerah penelitian ini perlu diterapkan untuk meningkatkan produksi sayuran. 


\section{Analisis Regresi Fungsi Produksi Cobb-Douglas}

Untuk menduga hubungan antara produksi $\left(\mathrm{Y}_{\mathrm{i}}\right)$ sebagai variabel terikat (dependent variable) dengan faktor produksi $\left(\mathrm{X}_{\mathrm{i}}\right)$ yang diduga mempengaruhi $\mathrm{Y}$ sebagai variabel bebas (independen variable) digunakan fungsi produksi Cobb-Douglas. Dalam perhitungan, fungsi produksi Cobb-Douglas dapat diubah dalam bentuk regresi linier berganda dengan cara ditransformasikan dalam bentuk logaritma. Regresi linier berganda ini di analisis dengan menggunakan program Eviews 7.

Sawi

Hasil analisis regresi untuk jenis sayuran sawi dapat dilihat pada tabel dibawah ini

Tabel 5. Hasil Estimasi Fungsi Produksi Cobb-Douglas Pada Usahatani Sayuran Sawi

\begin{tabular}{rrrrr}
\hline \hline Variable & Coefficient & Std. Error & t-Statistic & Prob. \\
\hline \hline LGX1 & 0.502001 & 0.231388 & 2.169520 & 0.0406 \\
LGX2 & 0.276955 & 0.124717 & 2.220666 & 0.0365 \\
LGX3 & 0.298817 & 0.137035 & 2.180594 & 0.0397 \\
LGX4 & 0.007484 & 0.083356 & 0.089778 & 0.9292 \\
LGX5 & -0.030995 & 0.079216 & -0.391267 & 0.6992 \\
CGX6 & -0.017661 & 0.176148 & -0.100263 & 0.9210 \\
\hline \hline R-squared & 6.265099 & 1.346535 & 4.652755 & 0.0001 \\
Adjusted R-squared & 0.944285 & & & \\
F-statistic & 0.929751 & & & \\
Prob(F-statistic) & 64.96915 & & & \\
\hline \hline
\end{tabular}

Dari hasil estimasi di atas dapat dituliskan persamaaan untuk usahatani sayuran sawi di daerah penelitian sebagai berikut :

$\mathrm{Y}_{\text {sawi }}=1840772 \cdot \mathrm{X}_{1}^{0,502} \cdot \mathrm{X}_{2}^{0,276} \cdot \mathrm{X}_{3}^{0,298} \cdot \mathrm{X}_{4}^{0,007} \cdot \mathrm{X}_{5}^{-0,030} \cdot \mathrm{X}_{6}^{-0,017}$

Uji koefisien determinasi digunakan untuk mengetahui seberapa besar proporsi dari faktor-faktor produksi berpengaruh terhadap hasil produksi. Hasil analisis dengan program eviews 7 dapat dilihat pada nilai Adjusted R-squared sebesar 0,929. Hal ini berarti 92,9 persen variasi hasil produksi sayuran sawi dipengaruhi oleh faktor-faktor produksi yang terdapat dalam model, sedangkan sisanya sebesar 7,1 persen dipengaruhi oleh faktor-faktor lain diluar model.

Pengaruh penggunaan faktor - faktor produksi secara bersama - sama terhadap jumlah produksi sayuran sawi yang dihasilkan dapat diketahui dengan menggunakan uji $F$, dari hasil analisis diperoleh nilai pada F-statistic sebesar 64,96915 dengan probabilitas sebesar 0,000000. Nilai probabilitas yang lebih kecil dari alfa $(0,05)$ menunjukkan hasil yang signifikan, artinya variabel bebas yang terdapat dalam model secara bersama-sama berpengaruh terhadap produksi sayuran sawi di Kecamatan Sungai Gelam. Hasil penelitian ini sesuai dengan yang dilakukan oleh Etik Purnami dkk (2012) pada komoditas sawi di Kelurahan Maharatu Kecamatan Marpoyan Damai Kota Pekanbaru yang menyatakan bahwa secara bersama-sama variabel benih, pupuk kandang, pupuk urea, pupuk NPK, pestisida dan tenaga kerja berpengaruh terhadap produksi sawi.

Pengaruh faktor produksi terhadap produksi sawi secara parsial dapat diketahui dengan melihat nilai probabilitas pada masing-masing variabel faktor produksi. Nilai probabilitas yang lebih kecil dari alfa $(0,05)$ menunjukkan hasil yang signifikan pada tingkat kepercayaan 95 persen. Berdasarkan hasil analisis diatas, didapat bahwa nilai probabilitas faktor produksi luas lahan $\left(\mathrm{x}_{1}\right)$, benih $\left(\mathrm{x}_{2}\right)$ dan pupuk kandang $\left(\mathrm{x}_{3}\right)$ lebih kecil dari alfa $(0,05)$ pada tingkat kepercayaan 95 persen, yang berarti secara parsial atau individu variabel bebas tersebut berpengaruh nyata terhadap produksi sayuran sawi. Sedangkan, nilai probabilitas faktor produksi yang meliputi pupuk urea $\left(x_{4}\right)$, pestisida $\left(x_{5}\right)$ dan tenaga kerja $\left(x_{6}\right)$ lebih besar dari alfa $(0,05)$ pada tingkat kepercayaan 95 persen, yang berarti secara parsial atau individu variabel bebas tersebut tidak berpengaruh nyata terhadap produksi sayuran sawi. 
Luas lahan berpengaruh terhadap produksi sawi dengan elastisitas sebesar 0,502 dan bertanda positif yang berarti bahwa kenaikan luas lahan sebesar $1 \%$ akan meningkatkan produksi sebesar 0,502 persen (cateris paribus). Luas lahan yang dimiliki petani sayuran di daerah penelitian mempengaruhi produksi yang akan diperoleh. Hal ini sesuai dengan teori menurut Suratiyah (2011) yang menyatakan bahwa dipandang dari sudut efisiensi, semakin luas lahan yang diusahakan maka semakin tinggi produksi dan pendapatan per kesatuan luasnya.

Benih berpengaruh terhadap produksi sawi dengan elastisitas sebesar 0,276 dan bertanda positif yang berarti bahwa kenaikan benih sebesar 1 persen akan meningkatkan produksi sebesar 0,276 persen. Benih yang bermutu menjanjikan produksi yang baik dan bermutu pula jika diikuti dengan perlakuan agronomi yang baik dan input teknologi yang berimbang. Sebaliknya, bila benih yang digunakan tidak berkualitas baik maka produksinya banyak tidak menjanjikan atau tidak lebih baik dari penggunaan benih bermutu. Penggunaan benih berkualitas diharapkan mampu mengurangi berbagai faktor resiko kegagalan panen.

Pupuk kandang berpengaruh terhadap produksi sawi dengan elastisitas sebesar 0,298 dan bertanda positif yang berarti bahwa kenaikan pupuk kandang sebesar 1 persen akan meningkatkan produksi sawi sebesar 0,298 persen. Produksi sawi dapat ditingkatkan melalui budidaya yang baik, yaitu pemeliharaan dan pemupukan yang tepat. Pemupukan dengan menggunakan pupuk kandang (kotoran ayam, kotoran sapi dan kotoran kambing) sangat baik untuk pertumbuhan sawi dengan kualitas yang baik dan dapat meningkatkan produksi sawi caisim (Lingga, 1991).

Bayam

Hasil analisis regresi untuk jenis sayuran bayam dapat dilihat pada tabel dibawah ini:

Tabel 6. Hasil Estimasi Fungsi Produksi Cobb-Douglas Pada Usahatani Sayuran Bayam

\begin{tabular}{ccccc}
\hline \hline Variable & Coefficient & Std. Error & t-Statistic & Prob. \\
\hline \hline LGX1 & 0.373871 & 0.169363 & 2.207515 & 0.0375 \\
LGX2 & 0.306523 & 0.114900 & 2.667740 & 0.0137 \\
LGX3 & 0.233386 & 0.112741 & 2.070097 & 0.0499 \\
LGX4 & 0.186658 & 0.085922 & 2.172412 & 0.0404 \\
LGX5 & 0.039843 & 0.056881 & 0.700452 & 0.4907 \\
LGX6 & -0.009109 & 0.087330 & -0.104300 & 0.9178 \\
C & 6.121216 & 1.090479 & 5.613328 & 0.0000 \\
\hline \hline R-squared & 0.984102 & & & \\
Adjusted R-squared & 0.979954 & & & \\
F-statistic & 237.2847 & & & \\
Prob(F-statistic) & 0.000000 & & & \\
\hline \hline
\end{tabular}

Dari hasil estimasi di atas dapat dituliskan persamaaan untuk usahatani sayuran bayam di daerah penelitian sebagai berikut:

$Y_{\text {bayam }}=1321295,634 \cdot X_{1}^{0,373} \cdot X_{2}^{0,306} \cdot X_{3}^{0,233} \cdot X_{4}^{0,186} \cdot X_{5}^{0,039} \cdot X_{6}^{-0,009}$

Uji koefisien determinasi digunakan untuk mengetahui seberapa besar proporsi dari faktor-faktor produksi berpengaruh terhadap hasil produksi. Hasil analisis dengan program eviews 7 dapat dilihat pada nilai Adjusted R-squared sebesar 0,979. Hal ini berarti 97,9 persen variasi hasil produksi sayuran bayam dipengaruhi oleh faktor-faktor produksi yang terdapat dalam model, sedangkan sisanya sebesar 2,1 persen dipengaruhi oleh faktor-faktor lain diluar model.

Pengaruh penggunaan faktor - faktor produksi secara bersama - sama terhadap jumlah produksi sayuran bayam yang dihasilkan dapat diketahui dengan menggunakan uji $\mathrm{F}$, dari hasil analisis diperoleh nilai pada F-statistic sebesar 237.2847 dengan probabilitas sebesar 0,000000. Nilai probabilitas yang lebih kecil dari alfa $(0,05)$ menunjukkan hasil yang signifikan, artinya variabel bebas yang terdapat dalam model secara bersama-sama berpengaruh terhadap produksi sayuran bayam di Kecamatan Sungai Gelam. Hasil analisis regresi ini sesuai dengan hipotesis awal yang diajukan dalam 
penelitian, dimana diduga faktor produksi luas lahan, benih, pupuk, pestisida dan tenaga kerja secara bersama-sama berpengaruh terhadap jumlah produksi usahatani sayuran bayam di Kecamatan Sungai Gelam Kabupaten Muaro Jambi.

Pengaruh faktor produksi terhadap produksi bayam secara parsial dapat diketahui dengan melihat nilai probabilitas pada masing-masing variabel faktor produksi. Nilai probabilitas yang lebih kecil dari alfa $(0,05)$ menunjukkan hasil yang signifikan pada tingkat kepercayaan 95 persen. Berdasarkan hasil analisis diatas, didapat bahwa nilai probabilitas faktor produksi luas lahan $\left(\mathrm{x}_{1}\right)$, benih $\left(x_{2}\right)$ dan pupuk urea $\left(x_{4}\right)$ lebih kecil dari alfa $(0,05)$ pada tingkat kepercayaan 95 persen, yang berarti secara parsial atau individu variabel bebas tersebut berpengaruh nyata terhadap produksi bayam. Sedangkan nilai probabilitas yang meliputi pupuk kandang $\left(x_{3}\right)$, pestisida $\left(x_{5}\right)$ dan tenaga kerja $\left(x_{6}\right)$ lebih besar dari alfa $(0,05)$ pada tingkat kepercayaan 95 persen, yang berarti secara parsial atau individu variabel bebas tersebut tidak berpengaruh nyata terhadap produksi bayam.

Luas lahan berpengaruh terhadap produksi bayam dengan elastisitas sebesar 0,373 dan bertanda positif yang berarti bahwa kenaikan luas lahan sebesar 1 persen akan meningkatkan produksi sebesar 0,373 persen (cateris paribus). Hasil ini sesuai dengan teori Hernanto (1991) yang menyatakan bahwa dengan lahan usahatani sempit, akan membatasi petani berbuat pada rencana yang lebih lapang. Tanah yang sempit dengan kualitas tanah yang kurang baik akan merupakan beban bagi petani pengelola usahatani.

Benih berpengaruh terhadap produksi bayam dengan elastisitas sebesar 0,306 dan bertanda positif yang berarti bahwa kenaikan benih sebesar 1 persen akan meningkatkan produksi sebesar 0,306 persen. Hal ini sesuai dengan teori Anwar (2005) yang menyatakan bahwa keberhasilan budidaya sayuran utama di Indonesia sangat ditentukan oleh ketersediaan benih sayuran yang bermutu secara berkesinambungan.

Pupuk urea berpengaruh terhadap produksi sebesar 0,186 dan bertanda positif yang berarti bahwa kenaikan pupuk urea sebesar 1 persen akan meningkatkan produksi bayam sebesar 0,186 persen. Hal ini sesuai dengan teori Hardjowigeno (1987) dalam Dian (2012) yang menyatakan bahwa selain pemberian pupuk organik, pemberian pupuk urea sebagai sumber hara $\mathrm{N}$ merupakan usaha yang banyak dilakukan dalam meningkatkan produkstivitas sayuran. Pupuk urea sebagai sumber hara $\mathrm{N}$ dapat memperbaiki pertumbuhan vegetatif tanaman, dimana tanaman yang tumbuh pada tanah yang cukup $\mathrm{N}$, berwarna lebih hijau.

\section{Kangkung}

Hasil analisis regresi untuk jenis sayuran kangkung dapat dilihat pada tabel dibawah ini:

Tabel 7. Hasil Estimasi Fungsi Produksi Cobb-Douglas Pada Usahatani Sayuran Kangkung

\begin{tabular}{rrrrr}
\hline \hline Variable & Coefficient & Std. Error & t-Statistic & Prob. \\
\hline \hline LGX1 & -0.439073 & 0.137425 & -3.195007 & 0.0040 \\
LGX2 & 1.073677 & 0.160159 & 6.703821 & 0.0000 \\
LGX3 & 0.220211 & 0.091674 & 2.402118 & 0.0248 \\
LGX4 & 0.048095 & 0.069173 & 0.695292 & 0.4938 \\
LGX5 & 0.084105 & 0.055943 & 1.503407 & 0.1463 \\
LGX6 & 0.113744 & 0.122220 & 0.930655 & 0.3617 \\
C & 2.672915 & 0.743867 & 3.593273 & 0.0015 \\
\hline \hline R-squared & 0.976065 & & & \\
Adjusted R-squared & 0.969820 & & & \\
F-statistic & 156.3194 & & & \\
Prob(F-statistic) & 0.000000 & & & \\
\hline \hline
\end{tabular}

Dari hasil estimasi di atas dapat dituliskan persamaaan untuk usahatani sayuran kangkung di daerah penelitian sebagai berikut :

$Y_{\text {kangkung }}=469,89 \cdot X_{1}^{-0,439} \cdot X_{2}^{1,073} \cdot X_{3}^{0,220} \cdot X_{4}^{0,048} \cdot X_{5}^{0,084} \cdot X_{6}^{0,113}$ 
Uji koefisien determinasi digunakan untuk mengetahui seberapa besar proporsi dari faktor-faktor produksi berpengaruh terhadap hasil produksi. Hasil analisis dengan program eviews 7 dapat dilihat pada nilai Adjusted R-squared sebesar 0,969. Hal ini berarti 96,9 persen variasi hasil produksi sayuran kangkung dipengaruhi oleh faktor-faktor produksi yang terdapat dalam model, sedangkan sisanya sebesar 3,1 persen dipengaruhi oleh faktor-faktor lain diluar model. Pengaruh penggunaan faktor faktor produksi secara bersama - sama terhadap jumlah produksi sayuran kangkung yang dihasilkan dapat diketahui dengan menggunakan uji $\mathrm{F}$, dari hasil analisis diperoleh nilai pada $\mathrm{F}$-statistic sebesar 156,3194 dengan probabilitas sebesar 0,000000. Nilai probabilitas yang lebih kecil dari alfa $(0,05)$ menunjukkan hasil yang signifikan, artinya variabel bebas yang terdapat dalam model secara bersamasama berpengaruh terhadap produksi sayuran kangkung di Kecamatan Sungai Gelam.

Pengaruh faktor produksi terhadap produksi kangkung secara parsial dapat diketahui dengan melihat nilai probabilitas pada masing-masing variabel faktor produksi. Nilai probabilitas yang lebih kecil dari alfa $(0,05)$ menunjukkan hasil yang signifikan pada tingkat kepercayaan 95 persen. Berdasarkan hasil analisis diatas, didapat bahwa nilai probabilitas faktor produksi luas lahan $\left(x_{1}\right)$, benih $\left(x_{2}\right)$ dan pupuk kandang $\left(x_{3}\right)$ lebih kecil dari alfa $(0,05)$ pada tingkat kepercayaan 95 persen, yang berarti secara parsial atau individu variabel bebas tersebut berpengaruh nyata terhadap produksi kangkung. Sedangkan nilai probabilitas yang meliputi pupuk urea $\left(x_{4}\right)$, pestisida $\left(x_{5}\right)$ dan tenaga kerja $\left(x_{6}\right)$ lebih besar dari alfa $(0,05)$ pada tingkat kepercayaan 95 persen, yang berarti secara parsial atau individu variabel bebas tersebut tidak berpengaruh nyata terhadap produksi kangkung.

Luas lahan berpengaruh terhadap produksi kangkung dengan elastisitas sebesar 0,439 dan bertanda negatif yang berarti bahwa kenaikan luas lahan sebesar 1 persen akan mengakibatkan menurunnya produksi sebesar 0,439 persen (cateris paribus). Berdasarkan keadaan luas lahan di daerah penelitian pada usahatani kangkung, penggunaan lahan tidak seimbang dengan pengaplikasian benih, sehingga berdampak pada produksi sayuran itu sendiri. Hal ini diduga karena jarak tanam yang terlalu dekat yaitu kira-kira $10 \mathrm{~cm} \times 10 \mathrm{~cm}$, sedangkan rekomendasi jarak tanam yang dianjurkan untuk tanaman kangkung menurut Sunarjono (2013) yaitu sekitar $20 \mathrm{~cm}$ x $30 \mathrm{~cm}$. Menurut Harjadi (1996) dalam Pambayun (2008), pengaturan jarak tanam sangat berkaitan erat dengan kerapatan tanaman. Kerapatan tanaman akan mempengaruhi pertumbuhan dan perkembangan tanaman. Penggunaan jarak tanam yang rapat akan meningkatkan jumlah populasi namun kompetisi yang dialami tanaman juga semakin ketat. Kompetisi yang intensif antar tanaman dapat mengakibatkan perubahan morfologi pada tanaman, seperti berkurangnya organ yang terbentuk sehingga perkembangan tanaman menjadi terganggu. Oleh karena itu, jika bertambahnya penggunaan lahan sebesar 1 persen maka akan mengakibatkan penurunan produksi sebesar 0,439 persen.

Benih berpengaruh terhadap produksi kangkung dengan elastisitas sebesar 1,073 dan bertanda positif yang berarti bahwa kenaikan benih sebesar 1 persen akan meningkatkan produksi sebesar 1,073 persen. Hal ini sesuai dengan teori Anwar (2005) yang menyatakan bahwa keberhasilan budidaya sayuran utama di Indonesia sangat ditentukan oleh ketersediaan benih sayuran yang bermutu secara berkesinambungan.

Pupuk kandang berpengaruh terhadap produksi kangkung dengan elastisitas sebesar 0,220 dan bertanda positif yang berarti bahwa kenaikan pupuk kandang sebesar 1 persen akan meningkatkan produksi kangkung sebesar 0,220 persen. Penggunaan pupuk organik selain untuk meningkatkan produktivitas juga untuk melestarikan sumberdaya alam. Dalam rangka meningkatkan produktivitas tanaman sayuran, umumnya petani menggunakan pupuk kandang karena selain memperbaiki struktur tanah juga mendapatkan unsur hara mikro dan makro didalamnya. Juga dapat menciptakan kegemburan tanah yang baik dan ideal bagi pertumbuhan tanaman.

\section{Analisis Efisiensi Ekonomi Penggunaan Faktor-Faktor Produksi Sawi}


Hasil analisis efisiensi ekonomi penggunaan faktor produksi pada usahatani sayuran sawi dapat dilihat pada tabel dibawah ini:

Tabel 8. Perhitungan Efisiensi Ekonomi Penggunaan Faktor Produksi Pada Usahatani Sayuran Sawi

\begin{tabular}{ccccc}
\hline Variabel & Koefisien (bi) & Harga Input (pxi) & NPMxi & NPMxi/Pxi \\
\hline Luas lahan & 0,502001 & 2000000 & 24982955,9 & 12,49 \\
Benih & 0,276955 & 110000 & 3066953,25 & 27,88 \\
Pupuk kandang & 0,298817 & 650 & 3378,35 & 5,19 \\
\hline
\end{tabular}

Tabel 8 menunjukkan bahwa pada penggunaan faktor produksi untuk tanaman sawi yaitu luas lahan, benih dan pupuk kandang memiliki nilai efisiensi $>1$. Hal ini menunjukkan bahwa faktor-faktor produksi tersebut belum efisien dan untuk mencapai faktor produksi yang efisien maka perlu penambahan pengggunaan lahan, benih dan pupuk kandang.

Bayam

Hasil analisis efisiensi ekonomi penggunaan faktor produksi pada usahatani sayuran bayam dapat dilihat pada tabel dibawah ini:

Tabel 9. Perhitungan Efisiensi Ekonomi Penggunaan Faktor Produksi Pada Usahatani Sayuran Bayam

\begin{tabular}{ccccc}
\hline Variabel & Koefisien (bi) & Harga Input (pxi) & NPMxi & NPMxi/Pxi \\
\hline Luas lahan & 0,373871 & 2000000 & 19535350,8 & 9,76 \\
Benih & 0,306523 & 120000 & 602113,397 & 5,01 \\
Pupuk Urea & 0,186658 & 3000 & 170679,615 & 56,89 \\
\hline
\end{tabular}

Tabel 9 menunjukkan bahwa pada penggunaan faktor produksi untuk tanaman bayam yaitu luas lahan, benih dan pupuk urea memiliki nilai efisiensi $>1$. Hal ini menunjukkan bahwa faktor-faktor produksi tersebut belum efisien dan untuk mencapai faktor produksi yang efisien maka perlu penambahan pengggunaan lahan, benih, dan pupuk urea. Sedangkan pada penggunaan faktor produksi tenaga kerja memiliki nilai efisiensi $<1$.

\section{Kangkung}

Hasil analisis efisiensi ekonomi penggunaan faktor produksi pada usahatani sayuran kangkung dapat dilihat pada tabel dibawah ini:

Tabel 10. Perhitungan Efisiensi Ekonomi Penggunaan Faktor Produksi Pada Usahatani Sayuran Kangkung

\begin{tabular}{ccccc}
\hline Variabel & Koefisien (bi) & Harga Input (pxi) & NPMxi & NPMxi/Pxi \\
\hline Luas lahan & $-0,439073$ & 2000000 & -29995151 & $-14,99$ \\
Benih & 1,073677 & 35000 & 945067,05 & 27 \\
Pupuk & 0,220211 & 650 & 2479,53827 & 3,81 \\
Kandang & & & & \\
\hline
\end{tabular}

Tabel 10 menunjukkan bahwa pada penggunaan faktor produksi untuk tanaman kangkung yaitu benih dan pupuk kandang memiliki nilai efisiensi $>1$. Hal ini menunjukkan bahwa faktor-faktor produksi tersebut belum efisien dan untuk mencapai faktor produksi yang efisien maka perlu penambahan pengggunaan benih dan pupuk kandang. Sedangkan pada penggunaan faktor produksi luas lahan memiliki nilai efisiensi $<1$. Hal ini menunjukkan bahwa faktor-faktor produksi tersebut tidak efisien dan untuk mencapai faktor produksi yang efisien maka faktor produksi luas lahan harus dikurangi penggunaannya.

\section{KESIMPULAN}

Berdasarkan hasil penelitian pada beberapa jenis usahatani sayuran di Kecamatan Sungai Gelam diperoleh kesimpulan (1) Faktor - faktor produksi pada usahatani sayuran sawi, bayam dan kangkung secara bersama - sama berpengaruh terhadap produksi sayuran sawi, bayam dan kangkung. Sementara, secara parsial penggunaan faktor produksi lahan, benih dan pupuk kandang berpengaruh signifikan terhadap produksi sawi dan kangkung. Sementara untuk usahatani sayuran bayam penggunaan faktor produksi lahan, benih, pupuk kandang dan pupuk urea berpengaruh signifikan terhadap produksi bayam, dan (2) Penggunaan faktor - faktor produksi yang masuk dalam kategori 
belum efisien pada usahatani sawi yaitu luas lahan, benih dan pupuk kandang, untuk usahatani sayuran bayam meliputi luas lahan, benih dan pupuk urea, sementara pada usahatani kangkung meliputi benih, pupuk kandang, pupuk urea dan pestisida.

\section{UCAPAN TERIMA KASIH}

Ucapan terima kasih disampaikan kepada Dekan Fakultas Pertanian Universitas Jambi dan Ketua Jurusan Agribisnis Fakultas Pertanian Universitas Jambi yang telah memfasilitasi pelaksanaan penelitian ini. Selain itu ucapan terima kasih juga penulis sampaikan kepada Kepala Kecamatan Sungai Gelam Kabupaten Muaro Jambi, Kepala Desa Kebon IX dan Kepala Desa Mekar Jaya yang memfasilitasi pelaksanaan penelitian di lapangan.

\section{DAFTAR PUSTAKA}

Anwar, Aswaldi. 2005. Perbenihan Sayuran di Indonesia Kondisi Terkini dan Prospek Bisnis Benih Sayuran. Diunduh dari http://jesl.journal.ipb.ac.id/index.php/jurnalagronomi/article/viewFile/1513/586. Diakses pada tanggal 28 Desember 2015.

Dian, Eka Kiswati. 2012. Pengaruh Pupuk Urea Terhadap Pertumbuhan Tanaman Sayuran. Diunduh dari https://hortikulturapolinela.files.wordpress.com/2012/10/eka-dian-kiswati.pdf. Diakses pada tanggal 28 Desember 2015.

Gujarati, Damodar. 2003. Ekonometri Dasar. Terjemahan: Sumarno Zain. Jakarta: Erlangga.

Hernanto, Fadholi. 1991. Ilmu Usahatani. Penebar Swadaya. Jakarta.

Pambayun, Ratna. 2008. Pengaruh Jarak Tanam Terhadap Produksi Beberapa Sayuran Indigenous. Diunduh dari http://repository.ipb.ac.id/bitstream/handle/123456789/2760/A08rpa.pdf?sequence=4. Diakses pada tanggal 28 Desember 2015.

Purnami, Etik, Shorea Khaswarina, Suardi Tarumun. 2012. Pengaruh Faktor-Faktor Produksi Terhadap Produksi Sawi Di Kelurahan Maharatu Kecamatan Marpoyan Damai Kota Pekanbaru. Diunduh dari http://ejournal.unri.ac.id/index.php/IJAE/article/view/1542. Diakses pada tanggal 8 desember 2015.

Sunarjono, Hendro. 2013. Bertanam 36 Jenis Sayur. Penebar Swadaya. Jakarta.

Sunaryono, Hendro. 2003. Kunci Bercocok Tanam Sayur-Sayuran Penting Di Indonesia (Produksi Hortikultura II). Sinar Baru Algensindo. Bandung.

Suratiyah, Ken. 2011. Ilmu Usahatani. Penebar Swadaya. Jakarta.

Usman, Rianse dan Abdi. 2012. Metodologi Penelitian Sosial Dan Ekonomi (Teori Dan Aplikasinya). Alfabeta. Bandung.

Wibisono, Hariawan. 2011. Analisis Efisiensi Usahatani Kubis (Studi Empiris Di Desa Banyuroto Kecamatan Kawangan Kabupaten Diunduh dari http://core.ac.uk/download/pdf/11727453.pdf . Diakses pada tanggal 20 April 2015.

Zulkarnain. 2010. Dasar Dasar Hortikultura. Bumi Aksara. Jakarta. 